\title{
Five Mutant Alleles of the Insulin Receptor Gene in Patients with Genetic Forms of Insulin Resistance
}

\author{
Takashi Kadowaki," Hiroko Kadowaki," Matthew M. Rechler, ${ }^{*}$ Manuel Serrano-Rios," \\ Jesse Roth," Phillip Gorden," and Simeon I. Taylor* \\ ${ }^{*}$ Diabetes Branch and ${ }^{\ddagger}$ Molecular, Cellular, and Nutritional Endocrinology Branch, National Institute of Diabetes and Digestive and \\ Kidney Diseases, National Institutes of Health, Bethesda, Maryland 20892; and ${ }^{8}$ Centro Especial Ramon y Cajal, Madrid, Spain 28003
}

\begin{abstract}
The nucleotide sequence was determined for all 22 exons of the insulin receptor gene from three patients with genetic syndromes associated with extreme insulin resistance. In all three patients, insulin resistance was caused by decreased insulin binding to the cell surface. The patient with leprechaunism (leprechaun/Winnipeg) came from a consanguineous pedigree and was homozygous for a missense mutation substituting arginine for $\mathrm{His}^{209}$ in the $\alpha$-subunit of the insulin receptor. The other two patients were both compound heterozygotes with a nonsense mutation in one allele of the insulin receptor gene, and a missense mutation in the other allele. In the patient with the Rabson-Mendenhall syndrome (patient RM-1), the missense mutation substituted lysine for $\mathrm{Asn}^{15}$ in the $\alpha$-subunit. In the patient with type $A$ extreme insulin resistance (patient A-1), the missense mutation substituted serine for $\mathrm{Asn}^{462}$ in the $\alpha$-subunit. Both nonsense mutations markedly reduced the levels of insulin receptor mRNA transcribed from the alleles with the nonsense mutation as compared to the transcripts from the other allele. The reduction in the level of mRNA would be predicted to greatly reduce the rate at which the truncated receptors would be synthesized. Furthermore, the truncated receptors would be severely impaired in their ability to mediate insulin action. (J. Clin. Invest. 1990. 86:254-264.) Key words: diabetes mellitus • leprechaunism • Rabson-Mendenhall syndrome $\bullet$ nonsense mutation
\end{abstract}

\section{Introduction}

The mechanism of insulin action involves multiple steps, many of which have not been characterized in detail. Defects in any of these steps may give rise to insulin resistance. In as much as the insulin receptor is responsible for mediating the first step in insulin action, the insulin receptor gene is a candidate to be the locus for mutations causing insulin resistance. Indeed, mutations have been identified in the insulin receptor gene in patients with leprechaunism (1-3) and type A extreme insulin resistance (4-8).

We have investigated three patients with genetic syndromes associated with extreme insulin resistance, all of whom have been reported to have a marked (80-90\%) decrease in insulin binding to the cell surface (9-14). One patient was homozygous for a missense mutation substituting arginine for

Address reprint requests to Simeon I. Taylor, M.D., National Institutes of Health, Bldg 10, Room 8S-243, Bethesda, MD 20892.

Received for publication 27 December 1989 and in revised form 15 February 1990.

The Journal of Clinical Investigation, Inc.

Volume 86, July 1990, 254-264
$\mathrm{His}^{209}$ in the $\alpha$-subunit. The other two patients were compound heterozygotes for one allele with a nonsense mutation and one allele with a missense mutation. Both of the missense mutations were also located in the $\alpha$-subunit: substituting lysine for $\mathrm{Asn}^{15}$ or serine for Asn ${ }^{462}$. Like most premature chain termination mutations in several genes $(3,15-18)$, the two nonsense mutations (at codons 133 and 1000) reduced the level of mRNA transcribed from the mutant allele.

This study supports the growing body of evidence that mutations in the insulin receptor gene are the cause of genetic syndromes associated with extreme insulin resistance such as leprechaunism, type A extreme insulin resistance, and the Rabson-Mendenhall syndrome (1-8, 19-21). The application of the polymerase chain reaction combined with direct sequencing of amplified genomic DNA greatly facilitates determinations of nucleotide sequence and identification of mutations $(3,22,23)$.

\section{Methods}

Patients (Table I). The patient RM-1 has the Rabson-Mendenhall syndrome, a genetic syndrome associated with extreme insulin resistance, acanthosis nigricans, dental dysplasia, dystrophic nails, and precocious puberty $(12,24)$. Patient A-1 has the syndrome of type A extreme insulin resistance associated with acanthosis nigricans and hyperandrogenism (25). Leprechaun/Winnipeg (26) and leprechaun/ Minn-1 (9) had the syndrome of leprechaunism. In addition, we have studied the insulin resistant father of another patient with leprechaunism, leprechaun/Ark-1 (1, 27-29).

Patients A-1 (9), RM-1 (12), and leprechaun/Minn-1 (9) had markedly decreased numbers of insulin receptors on the surface of their Epstein-Barr' virus (EBV)-transformed lymphocytes (Table I). Leprechaun/Winnipeg (14) has been reported to have decreased insulin binding to the surface of cultured skin fibroblasts (Table I). The rate of receptor biosynthesis has been reported to be normal in EBV-transformed lymphoblasts from patient RM-1 (13), but decreased in cells from patient A-1 (11). Nonsense mutations have been identified in one allele of the insulin receptor gene in both leprechaun/Minn-1 (3) and the father of leprechaun/Ark-1 (1). In addition, indirect evidence suggests that there is a mutation in the second allele of the insulin receptor gene of leprechaun/Minn-1, and that this mutation acts in a cis-dominant fashion to decrease insulin receptor mRNA levels $(3,30)$.

Genomic cloning. Genomic DNA was isolated from EBV-transformed lymphoblast cell lines using standard procedures (31). A subgenomic library was constructed from DNA digested with Nco I. The digested DNA was size-fractionated on agarose gels and fragments $\sim 3$ $\mathbf{k b}$ in length were ligated into $\lambda$ gt 10 (Stratagene, La Jolla, CA). From this library, we isolated clones containing 5 '-flanking DNA plus the portion of exon 1 upstream from the Nco I site.

Amplification of $C D N A$ and genomic DNA by polymerase chain reaction. The 22 exons of the insulin receptor gene were amplified by the polymerase chain reaction (PCR) catalyzed by Taq DNA polymer-

1. Abbreviations used in this paper: EBV, Epstein-Barr virus; PCR, polymerase chain reaction. 
Table I. Clinical Characteristics of Patients

\begin{tabular}{|c|c|c|c|c|c|c|}
\hline \multirow[b]{2}{*}{ Patient } & \multirow{2}{*}{$\begin{array}{l}\text { Fasting } \\
\text { plasma } \\
\text { insulin }\end{array}$} & \multirow{2}{*}{$\begin{array}{l}\text { Fasting } \\
\text { plasma } \\
\text { glucose }\end{array}$} & \multicolumn{4}{|c|}{$\left[{ }^{125} I\right]$ Lodoinsulin bound } \\
\hline & & & EBV-lymphoblasts & Monocytes & Fibroblasts & Reference \\
\hline & $\mu U / m l$ & $m g / d l$ & \multicolumn{4}{|c|}{ \% per $10^{7}$ cells $/ \mathrm{ml}$} \\
\hline A-1 & 125 & 200 & 1.4 & $\begin{array}{c}0.5 \\
\text { (normal, 3-11) }\end{array}$ & 1.6 & $9,11,25$ \\
\hline Leprechaun/Winnipeg & $>600$ & $13-92$ & - & - & 0.8 & 26 \\
\hline RM-1 & 1,150 & $>200$ & 1.0 & - & 1.6 & 12,24 \\
\hline $\begin{array}{l}\text { Father } \\
\text { (Leprechaun/Ark-1) }\end{array}$ & 90 & 71 & 31 & $\begin{array}{c}\quad 4 \\
\text { (normal, 10-18) }\end{array}$ & - & 27,29 \\
\hline Leprechaun/Minn-1 & 500 & 40 & 1.0 & - & 1.0 & 9 \\
\hline Normal range & $<20$ & $60-105$ & $12-62$ & (see above) & $3-7$ & - \\
\hline
\end{tabular}

ase using the patient's genomic DNA as template as described previously $(3,32)$. Primers were chosen in the introns flanking each exon (reference 33 and Table II). For exon 1, the method was modified to minimize technical problems caused by the high GC content of this exon (34-40). 7-Deaza-dGTP $(150 \mu \mathrm{M})$ in addition to dGTP $(50 \mu \mathrm{M})$ was included in the reaction mixture to amplify this exon $(33,41)$.

cDNA was synthesized and amplified according to the method of Frohman et al. (42) as described in more detail elsewhere (3). The cDNA was used as template for amplification by PCR as described above.

Direct sequencing of amplified genomic DNA. The nucleotide sequence of amplified genomic DNA was determined directly by the method of Gibbs et al. (22) as modified by Kadowaki et al. (3), using appropriate oligonucleotides as sequencing primers. Exons 11 and 22 have regions of DNA with high GC content, and exon 1 has high GC content throughout its length. Accordingly, we used Taq DNA polymerase rather than T7 DNA polymerase as the enzyme to sequence these three exons. The use of Taq DNA polymerase allows the sequencing reactions to be carried out at high temperatures that minimize the secondary structure of the template. In the case of exon 1,7-deaza-dGTP $(150 \mu \mathrm{M})$ was included in the sequencing reaction according to the methods suggested for the TaqTrack Deaza sequencing kit (Promega Biotec, Madison, WI).

Allele-specific oligonucleotide hybridization. One-tenth of the amplified genomic DNA or the amplified cDNA was analyzed by electro- phoresis through a $1.8 \%$ agarose gel and transferred to nylon membranes (Schleicher \& Schuell, Inc., Keene, NH). The DNA blots were hybridized with ${ }^{32} \mathrm{P}$-labeled synthetic oligonucleotides that were specific for either the wild-type or mutant sequences $(3,6,8)$.

Numbering systems for amino acids and nucleotides. We have numbered the amino acids of the insulin receptor according to Ebina et al. (36). The nucleotides in the coding sequence of the gene are numbered according to Ullrich et al. (35). Nucleotides in the 5 '-flanking DNA are assigned negative numbers according to their distance from the translation start site. Nucleotides in introns are numbered according to their distance from intron-exon boundaries $(33,34)$ : negative numbers refer to the distance from the 5 -end of the exon; positive numbers refer to the distance from the 3 '-end of the exon.

\section{Results}

\section{Determination of nucleotide sequences of amplified fragments of the insulin receptor gene}

Using oligonucleotides complementary to introns flanking each of the exons (Table II), we used the PCR catalyzed by Taq DNA polymerase to amplify all of the 22 exons of the insulin receptor gene. Thereafter, the method of direct sequencing (3, 22) was used to determine the nucleotide sequences of the

Table II. Oligonucleotide Primers for Amplification of Exons by PCR

\begin{tabular}{|c|c|c|c|}
\hline Exon No. & Strand* & Oligonucleotide sequence & Nucleotide No. \\
\hline 1 & $\mathbf{S}$ & 5'-GGGCGTGGAAGAGAAGGACG-3' & Exon $1,-119 \rightarrow-100$ \\
\hline 1 & $\mathbf{A}$ & 5'-GATCGATTTTGGCTTGGGTG-3' & Intron $1,+74 \rightarrow+55$ \\
\hline 4 & $\mathbf{S}$ & 5'-GATGTCTGAAGGACCTTGGATACCG-3' & Intron $3,-75 \rightarrow-51$ \\
\hline 4 & A & 5'-GCTCACAGCTCAGAGGGACATGGAG-3' & Intron $4,+64 \rightarrow+40$ \\
\hline 5 & $\mathbf{S}$ & 5'-AGCCTGAGGGTTATCTTCTCACC-3' & Intron $4,-90 \rightarrow-68$ \\
\hline 16 & $\mathbf{S}$ & 5'-CCTTTCTGCAGAGTCCCATGAG-3' & Intron $15,-58 \rightarrow-37$ \\
\hline 16 & A & 5'-CAATGGTGAAGGCAAAGGAAGC-3' & Intron $16,+68 \rightarrow+47$ \\
\hline 21 & $\mathbf{S}$ & 5'-GTCTAAATGGCTTCTTTGTTACTAC-3' & Intron $20,-44 \rightarrow-20$ \\
\hline 21 & A & 5'-TACCCTTTCAACGAACACCTC-3' & Intron $21,+49 \rightarrow+29$ \\
\hline 22 & $\mathbf{S}$ & 5'-GACTCACCCAGGACGTGTCCTTC-3' & Intron $21,-33 \rightarrow-11$ \\
\hline 22 & A & 5'-CTCCAGGTTCACAGTTAAATCC-3' & Exon $22,4369 \rightarrow 4348$ \\
\hline
\end{tabular}

To amplify most of the exons, we used oligonucleotides primers suggested by Seino et al. (33). However, for exons $1,4,5,16,21$, and 22 , we used the oligonucleotides listed below. * The sense and antisense strands of DNA are indicated by $S$ and $A$, respectively. To amplify each exon, two oligonucleotide primers were used: an upstream primer with the sequence derived from the sense strand, and a downstream primer with the sequence derived from the antisense strand. 

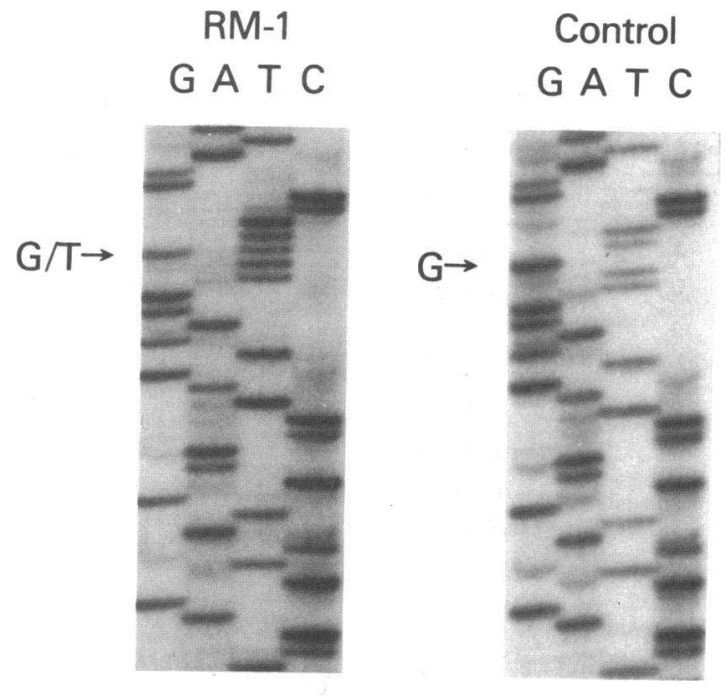

$\operatorname{Arg}^{14} \quad$ Asn $^{15} \quad$ Asn $^{16}$

Normal: $5^{\prime}$ - C G G - A A C - A A C - 3' $3^{\prime}-\mathrm{G} C \mathrm{C}-\mathrm{T}$ TG $-\mathrm{T} T \mathrm{G}-5^{\prime}$

Mutant: $5^{\prime}$ - C G G - A A A - A A C - 3' $3^{\prime}-$ G C C - T T T - T T G - 5'

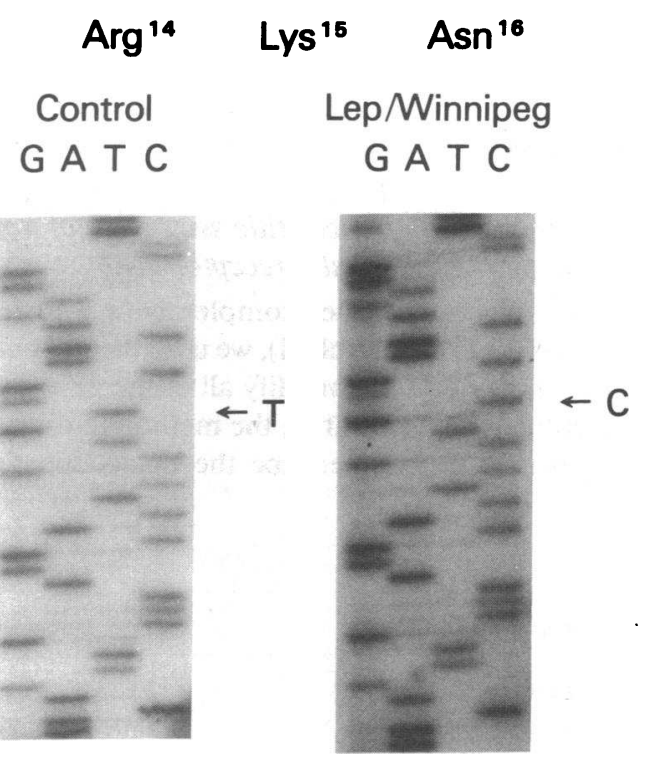

\section{Cys $^{208} \mathrm{His}^{209} \mathrm{Ser}^{210}$}

Normal: $5^{\prime}-$ T G C - C A C - A G C - 3' $3^{\prime}-A$ C G - GTG - T C G - 5'

Mutant: $\quad 5^{\prime}-$ T G C - C G C - A G C - 3' 3' - A C G - GC) - T C G - 5'

$$
\text { Cys }{ }^{208} \operatorname{Arg}^{209} \operatorname{Ser}^{210}
$$

Figure 1. Partial nucleotide sequence of two mutant alleles. Fragments of genomic DNA including exon 2 from patient RM-1 (top) and exon 3 from leprechaun/Winnipeg (bottom) were amplified by PCR. Then the sense strands of DNA were amplified, and the nucleotide sequences were determined. These are the portions of the se-
Table III. Five Mutant Alleles of the Insulin Receptor Gene

\begin{tabular}{|c|c|c|c|c|}
\hline Patient & $\begin{array}{l}\text { Codon } \\
\text { No. }\end{array}$ & $\begin{array}{l}\text { Exon } \\
\text { No. }\end{array}$ & Wild-Type & Mutant \\
\hline \multirow[t]{2}{*}{ RM-1 } & 15 & 2 & Asn $(A A C)$ & Lys $(A A A)$ \\
\hline & 1,000 & 17 & $\operatorname{Arg}(C G A)$ & Opal $(T G A)$ \\
\hline \multirow[t]{2}{*}{ A-1 } & 133 & 2 & $\operatorname{Trp}(T G G)$ & Amber $(T A G)$ \\
\hline & 462 & 6 & Asn $(A A T)$ & $\operatorname{Ser}(A G T)$ \\
\hline Leprechaun/Winnipeg* & 209 & 3 & His $(C A C)$ & $\operatorname{Arg}(C G C)$ \\
\hline
\end{tabular}

* Leprechaun/Winnipeg was a member of a consanguineous pedigree and was homozygous for the $\mathrm{Arg}^{209}$ mutation.

amplified genomic DNA (Fig. 1). The method of direct sequencing has several advantages, among them the ability to determine the sequences of both alleles of the insulin receptor gene simultaneously. At any position where the two alleles differ, two bands will be visible in the sequencing ladder (Fig. 1, top); each of the two bands will have approximately half of the normal intensity.

In this study, we have used this approach to identify mutations in the insulin receptor genes from three patients with genetic forms of insulin resistance. Each patient has two mutant alleles of the insulin receptor gene (Table III, Fig. 2): (a) Leprechaun/Winnipeg is a member of a consanguineous pedigree (26) and is homozygous for a missense mutation substituting arginine $(C G C)$ for histidine $(C A C)$ at codon 209 (Fig. 1, bottom). (b) Patient RM-1 (12) is a compound heterozygote. In one allele, the patient has a nonsense mutation substituting the opal chain termination codon $(T G A)$ for arginine $(C G A)$ at codon 1,000. In the other allele, there is a missense mutation substituting lysine $(A A A)$ for asparagine $(A A C)$ at codon 15 (Fig. 1, top). (c) Patient A-1 (25) is a compound heterozygote. In one allele, the patient has a nonsense mutation substituting the amber chain termination codon (TAG) for tryptophan $(T G G)$ at codon 133. In the other allele, there is a missense mutation substituting serine $(A G T)$ for asparagine $(A A T)$ at codon 462 . All five mutations were confirmed by allele-specific oligonucleotide hybridization. Genomic DNA was amplified by PCR a second time, and the amplified DNA was analyzed by Southern blotting. In each case, the oligonucleotide specific for the mutant sequence hybridized to DNA from the patient, but not from unrelated individuals. Because leprechaun/Winnipeg is homozygous for the $\mathrm{Arg}^{209}$ mutation, his amplified genomic DNA was not detected by hybridization with the oligonucleotide specific for the wild-type sequence (data not shown). In contrast, with patients A-1 and RM-1, oligonucleotides specific for the wild-type sequences $\left(\mathrm{Asn}^{15}\right.$ and $\mathrm{Arg}^{1,000}$ in patient $\mathrm{RM}-1 ; \operatorname{Trp}^{133}$ and $\mathrm{Asn}^{462}$ in patient A-1) hybridized to the patient's amplified DNA. Thus, the amplified genomic DNA from patients A-1 and RM- 1 hybridized to both wild-type and mutant probes, consistent with the conclusion that these two patients are compound heterozygotes (Figs. 3 and 4).

quencing ladder spanning the mutations at codon 15 (top) and 209 (bottom). For comparison, sequencing ladders are presented with amplified DNA from control subjects who were homozygous for the wild-type sequences at codons 15 and 462 . 


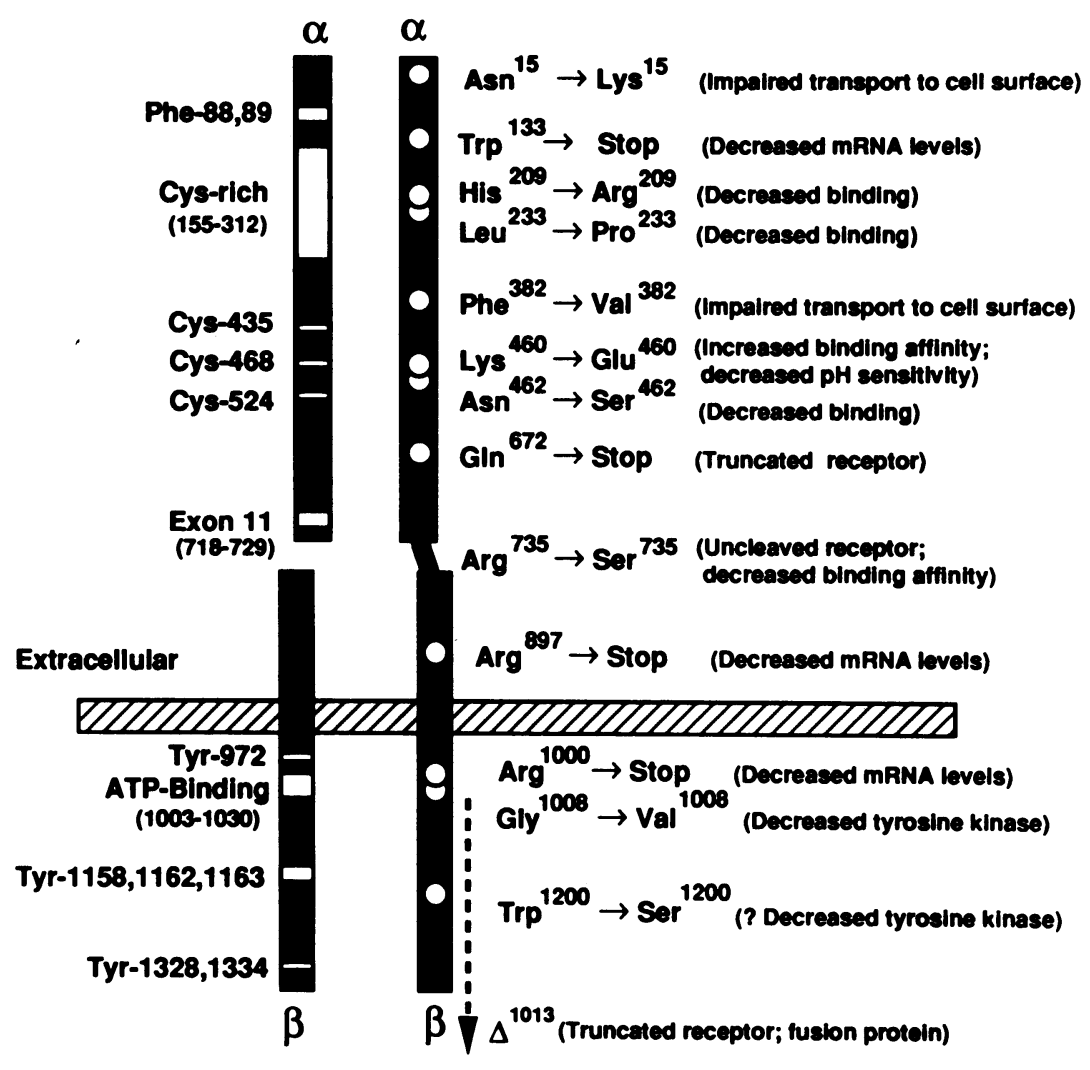

Figure 2. Mutations in the insulin receptor gene in insulin resistant patients. This is a structural map of the insulin receptor. Key structural landmarks are identified in the left half of the drawing of the receptor. $\mathrm{Phe}^{88}, \mathrm{Phe}^{89}(64)$, and the cysteine-rich domain $(35,38)$ have all been implicated as playing a role in the insulin binding domain. $\mathrm{Cys}^{435}, \mathrm{Cys}^{468}$, and $\mathrm{Cys}^{524}$ are candidates to contribute sulfhydryl groups for formation of the disulfide bonds between adjacent $\alpha$-subunits (65). Exon 11 is an exon that has been described to undergo variable splicing $(66,67)$. The five (68) or six (69) tyrosine residues that are sites of autophosphorylation are indicated. The consensus sequence for an ATP binding domain is located between amino acid residues $1,003-1,030(35,36)$.

The locations of all of the mutations reported to cause insulin resistance (1-8; also, this report) are noted in the right half of the drawing of the receptor.

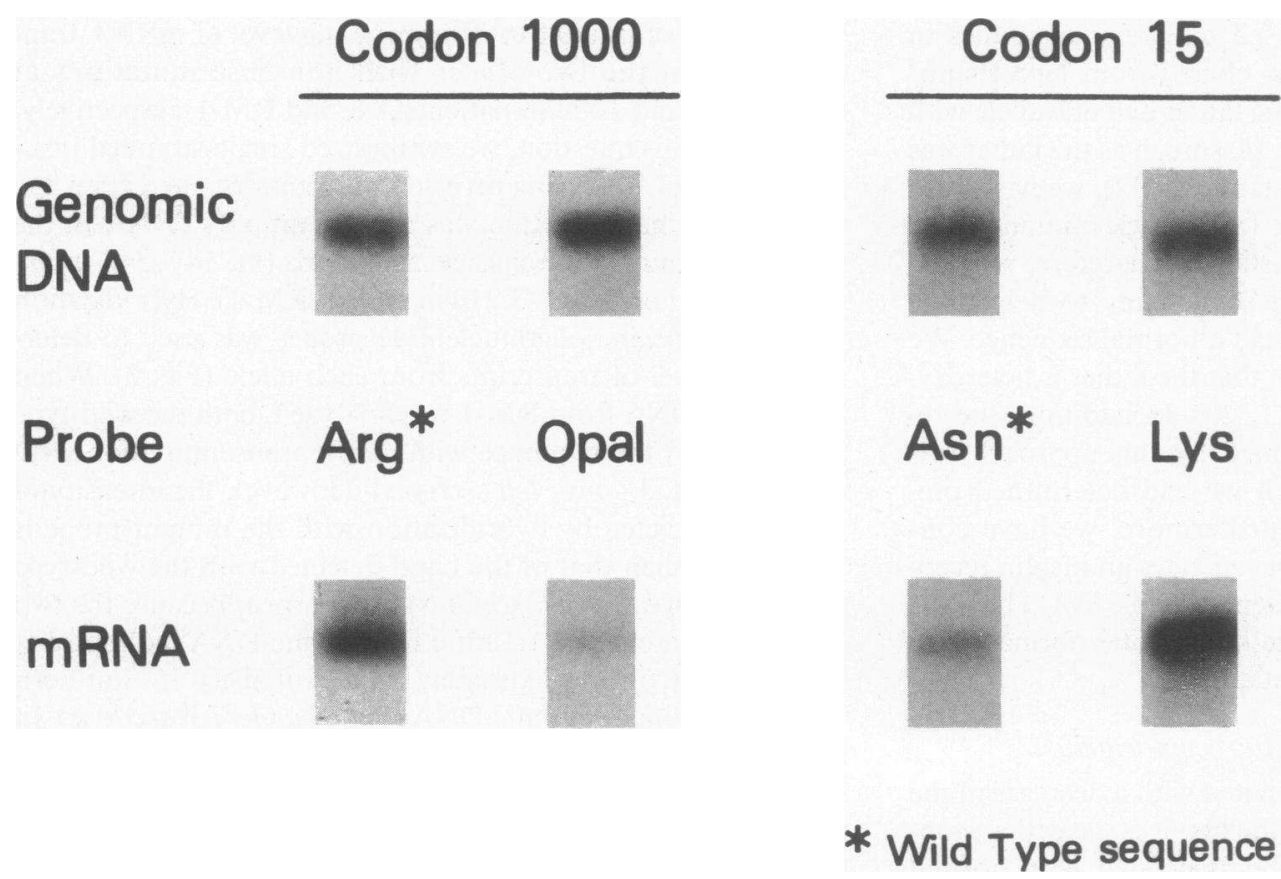

Figure 3. Allele-specific oligonucleotide hybridization of amplified cDNA from patient RM-1. Genomic DNA including exons 2 and 17 of the insulin receptor gene was amplified by PCR. Fragments of cDNA were amplified from total cellular RNA by RT-PCR with appropriate oligonucleotide primers: 5'-TGTGTCCCGGCATGGATATC-3' (nt. 149 $\rightarrow 168$, sense strand) plus 5'-ACGGAATCCAGGATACGGGAC-3' (nt. 548 $\rightarrow$ 528, antisense strand) to amplify the region spanning codon 15 ; and 5'-TACAGCGTGCGAATCCGGG-3' (nt. $2773 \rightarrow 2791$, sense strand) plus 5'TCGGAGACTGGCTGACTCGT3' (nt. 3210 $\rightarrow$ 3191, antisense strand) to amplify the region spanning codon 1,000 . Thereafter, amplified genomic DNA (50 ng DNA top sections) and amplified cDNA (40 ng; bottom sections) were analyzed by Southern blotting. Allelespecific oligonucleotides with the following specificities were used to probe the Southern blots: $\mathrm{Arg}^{1,000}$ or Opal ${ }^{1,000}$ (left sections); Asn ${ }^{15}$ or Lys ${ }^{15}$ (right sections). The autoradiographs were exposed for $2 \mathrm{~h}$. Based on densitometric scanning of the autoradiographs, we estimate that levels of mRNA transcribed from the Opal ${ }^{1,000}$ allele are reduced by $\sim 95 \%$ relative to the $\mathrm{Arg}^{1,000}$ allele; transcripts from the $\mathrm{Asn}^{15}$ allele are reduced by $\sim 90 \%$ relative to the $\mathrm{Lys}{ }^{15}$ allele. These estimates are based upon the assumption that the levels of mRNA are directly proportional to the intensity of the bands on the autoradiogram. 


\section{Codon 133}

\section{Genomic DNA}
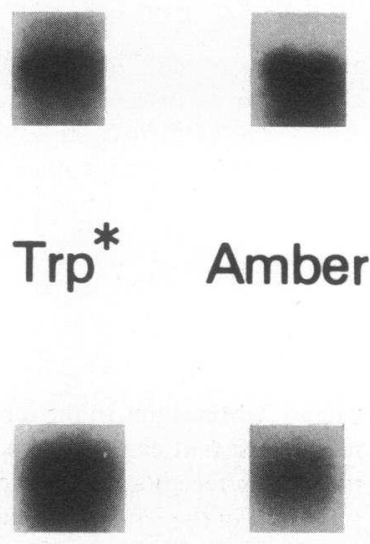

Codon 462
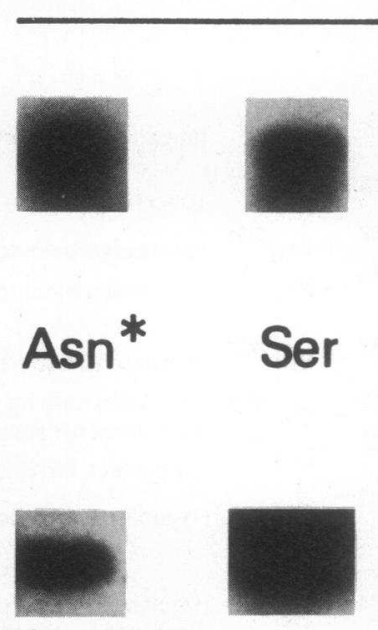

* Wild Type sequence

Figure 4. Allele-specific oligonucleotide hybridization of amplified cDNA from patient A-1. Genomic DNA including exons 2 and 6 of the insulin receptor gene was amplified by PCR. Fragments of cDNA were amplified from total cellular RNA ( $5 \mu \mathrm{g}$ ) by RT-PCR with appropriate oligonucleotide primers: 5'-TGTGTCCCGGCATGGATATC-3' (nt. 149 $\rightarrow 168$, sense strand) plus 5'-ACGGAATCCAGGATACGGGAC-3' (nt. 548 $\rightarrow 528$, antisense strand) to amplify the region spanning codon 133; and 5'-AAGAAGTTTCAGGAACCAAG-3' (nt. $1457 \rightarrow 1476$, sense strand) plus $5^{\prime}$ TTCACAAAGATGGCATACTG-3' (nt. $1829 \rightarrow 1810$, antisense strand) to amplify the region spanning codon 462. Thereafter, amplified genomic DNA (20 ng DNA; top sections) and amplified cDNA (50 ng; bottom sections) were analyzed by Southern blotting as described in the legend to Fig. 8. Allele-specific oligonucleotides with the following specificities were used to probe the Southern blots: $\operatorname{Trp}^{133}$ or Amber ${ }^{133}$ (left sections); Asn ${ }^{462}$ or Ser $^{462}$ (right sections). The autoradiographs were exposed for $3 \mathrm{~h}$. Based on densitometric scanning of the autoradiographs, we estimate that levels of mRNA transcribed from the Amber ${ }^{133}$ allele are reduced by $\sim 90 \%$ relative to the $\operatorname{Trp}^{15}$ allele; transcripts from the Asn ${ }^{462}$ allele are reduced by $\sim 80 \%$ relative to the $\mathrm{Ser}^{462}$ allele. These estimates are based upon the assumption that the levels of mRNA are directly proportional to the intensity of the bands on the autoradiogram.

In addition to the three patients noted above, we have also determined the nucleotide sequence of both alleles of the insulin receptor gene of the father of another patient with leprechaunism (leprechaun/Ark-1). Based on previous studies in which insulin receptor cDNA was cloned from leprechaun/ Ark-1 (1), we had concluded that the father had one allele with a nonsense mutation at codon 672 . Inasmuch as the father was hyperinsulinemic and insulin resistant $(30,32)$, we wished to determine whether heterozygosity for a single mutant allele was sufficient to cause insulin resistance. Therefore, we used the approach of PCR plus direct sequencing to determine whether the father's second allele had a normal sequence. We confirmed our previous conclusion that the father is heterozygous for the nonsense mutation $(1,29)$. In addition, the remainder of the sequence determined by this approach was entirely consistent with that which we had determined previously by cDNA cloning (1). Furthermore, we have confirmed that the father's second allele encodes an insulin receptor with a normal amino acid sequence (Table IV). Thus, the father is a compound heterozygote having one normal allele and one allele with a nonsense mutation.

\section{Expression of two alleles of insulin receptor gene}

Most nonsense mutations are associated with a decrease in the level of mRNA $(3,15-18)$. Nevertheless, it is clear that nonsense mutations can sometimes be associated with normal levels of mRNA. For example, we have previously identified two nonsense mutations in the insulin receptor gene of two patients with leprechaunism: at codons 672 and $897(1,3)$. The nonsense mutation at codon 672 in the paternal allele of leprechaun/Ark-1 did not appear to decrease the level of insulin receptor mRNA (1). In contrast, the nonsense mutation at codon 897 in the paternal allele of leprechaun/Minn-1 led to a $90 \%$ reduction in the level of insulin receptor mRNA (3). Thus, it was of interest to determine the level of mRNA transcribed from the two alleles with nonsense mutations at codons 133 and 1000 in patients A-1 and RM-1, respectively. To address this question, we synthesized single-stranded insulin receptor cDNA using reverse transcriptase. Thereafter, the polymerase chain reaction was used to amplify cDNA in the regions spanning the nonsense mutations (nt. 149-548 in patient A-1 and nt. 2,773-3,210 in patient RM-1). Hybridization with allele-specific oligonucleotide probes was used to determine the level of transcripts from each allele (Fig. 3). When amplified cDNA from RM-1 was analyzed, both the wild-type sequence and the sequence with the nonsense mutation were detected (Fig. 3, lower left sections). However, the intensity of the band detected by hybridization with the mutant probe is $\sim 90 \%$ less than that of the band detected with the wild-type probe (Fig. 3, lower left sections). In contrast, because the two alleles are present in a 1:1 ratio in genomic DNA, both probes detect bands of approximately equal intensity in Southern blots of amplified genomic DNA (Fig. 3, upper left sections). In similar studies, we analyzed the sequence of mRNA at codon 15. The intensity of the band detected by hybridization with the wild-type $\left(\operatorname{Asn}^{15}\right)$ probe is $\sim 90 \%$ less than that of the band detected with the probe specific for the Lys ${ }^{15}$-mutation (Fig. 2, lower right sections). In contrast, because the two alleles are present in a 1:1 ratio in genomic DNA, both probes detect bands of approximately equal intensity in Southern blots of amplified genomic DNA (Fig. 2, upper right sections). Thus, one can conclude that the level of mRNA transcribed from the 
allele with the nonsense mutation (haplotype, $\mathrm{Asn}^{15} / \mathrm{Opal}^{1,000}$ ) is markedly reduced in cells from patient $R M-1$ relative to the level of insulin receptor mRNA transcribed from the allele with the missense mutation (haplotype, $\mathrm{Lys}^{15} / \mathrm{Arg}^{1,000}$ ). In other words, the missense mutation (Lys ${ }^{15}$ ) and nonsense mutation (Opal ${ }^{1,000}$ ) map to different alleles of the insulin receptor gene in patient RM-1.

By a similar approach, we demonstrated that the missense mutation $\left(\mathrm{Ser}^{462}\right.$ ) and nonsense mutation (Amber ${ }^{133}$ ) map to different alleles of the insulin receptor gene in patient A-1 (Fig. 4, right sections). The allele with the nonsense mutation (haplotype, Amber ${ }^{133} / \mathrm{Asn}^{462}$ ) is expressed at much lower level than the allele with the missense mutation (haplotype, $\operatorname{Trp}^{133} / \operatorname{Ser}^{462}$ ).

\section{Polymorphisms of the insulin receptor gene}

Protein coding sequence. There are at least nine examples of silent polymorphisms in the nucleotide sequence that do not alter the predicted amino acid sequence of the insulin receptor protein (Table IV). A polymorphism at codon 838 (Asn- $A A C$ vs. Asn- $A A T$ ) noted in one allele from patient A-1 has not been reported previously, but has been detected in a Japanese patient with extreme insulin resistance (E. Imano, T. Kadowaki, H. Kadowaki, R. Kawamori, and S. I. Taylor, unpublished observations). The eight other silent polymorphisms have been reported previously $(1-3,5,6,8,19,34-36,41)$.

5 -Flanking sequence. We have determined the nucleotide sequence of a fragment of genomic DNA extending from the Nco I site at the initiator methionine codon in exon 1 to an Xho I site located 876 bp upstream. The nucleotide sequences of six independent clones from leprechaun/Minn-1 and one clone from a normal subject were identical to the sequence reported by Seino et al. (34) with two exceptions: $C$ instead of $G$ at position -456 and $C C$ instead of $C C C$ at positions -131 through -129 . Our sequences at these two positions were identical to those reported by other laboratories $(6,37-40)$. Four independent clones from patient A-1 differed at two po- sitions: $G$ instead of $A$ at position -603 and $A$ instead of $G$ at position -500 (Table V). At both of these positions, the sequence determined in the insulin receptor gene from patient A-1 is identical to that originally reported by Araki et al. (37). The polymorphism at nucleotide -603 is especially interesting because it is located at a consensus sequence for binding of the transcription factor Spl (43).

Intervening sequence. We have observed six polymorphisms in intervening sequences (Table V). One of the polymorphisms, located in the 3 '-portion of intron 2 , involves a variable number (10 vs. 11) of TC repeats. The remaining five polymorphisms are caused by single base pair changes. One of these polymorphisms, located in the $5^{\prime}$-portion of intron 8, alters a recognition site for Eco RI (GAATT $\underline{C}$ vs. GAATT $\underline{T}$ ). As a result, the sequence polymorphism can also be detected as a restriction fragment length polymorphism (RFLP): a 12.0-kb vs. a 9.4-kb band (data not shown). This same RFLP has also been noted in a Japanese patient with extreme insulin resistance (E. Imano, T. Kadowaki, H. Kadowaki, R. Kawamori, and S. I. Taylor, unpublished observations).

3'-Untranslated sequence. At nucleotide 4,265, we detected $A$ in one allele of leprechaun/Minn-1. In all other alleles, we have detected $G$ at that position (Table $V$ ).

\section{Discussion}

In these investigations, we have identified mutations in the insulin receptor gene in three patients, each with a distinct clinical syndrome associated with extreme insulin resistance. The two patients with the Rabson-Mendenhall syndrome (RM-1) and type A extreme insulin resistance (A-1) are compound heterozygotes for two different mutant alleles (Table III) that impair receptor function by different mechanisms. Thus, these two patients resemble two previously reported patients with leprechaunism (leprechaun/Ark-1 and leprechaun/ Minn-1) who were also compound heterozygotes. Interestingly, like the present patients (A-1 and RM-1), both of these

Table IV. Silent Polymorphisms of the Coding Sequence of the Insulin Receptor Gene

\begin{tabular}{|c|c|c|c|c|c|c|c|c|}
\hline Codon No. & Amino acid & Codon & A-1 & RM-1 & Lep/Winnipeg & Lep/Minn-1 & $\begin{array}{l}\text { Father of } \\
\text { Lep/Ark-1 }\end{array}$ & References \\
\hline \multirow[t]{2}{*}{-20} & Gly & GGG & + & + & + & + & + & $2,6,35,36,41$ \\
\hline & & GGA & - & - & - & - & - & 34 \\
\hline \multirow[t]{2}{*}{234} & Asp & GAC & + & + & + & + & + & $1,2,6,34-36,41$ \\
\hline & & GAT & - & - & - & + & - & 3 \\
\hline \multirow[t]{2}{*}{276} & Gln & CAG & + & + & + & + & + & $1,2,6,35,41$ \\
\hline & & CAA & - & - & - & - & - & 34,36 \\
\hline \multirow[t]{2}{*}{519} & Asp & GAC & + & + & - & + & + & $1,2,6,35,41$ \\
\hline & & GAT & + & - & + & - & + & $1,34,36$ \\
\hline \multirow[t]{2}{*}{523} & Ala & GCG & + & + & + & + & + & $1,6,34,36,41$ \\
\hline & & GCA & - & - & - & + & - & $2,35,41$ \\
\hline \multirow[t]{2}{*}{642} & Phe & TTC & + & + & - & + & + & $1,2,6,34-36,41$ \\
\hline & & TTT & - & - & + & - & + & 1 \\
\hline \multirow[t]{2}{*}{838} & Asn & AAC & + & + & + & + & + & $1,2,6,34-36,41$ \\
\hline & & AAT & + & - & - & - & - & \\
\hline \multirow[t]{2}{*}{1,058} & His & $\mathrm{CAC}$ & + & + & + & + & + & $1,2,6,34-36,41$ \\
\hline & & CAT & + & + & - & - & - & $5,8,41$ \\
\hline \multirow[t]{2}{*}{1,062} & Leu & CTC & + & + & + & + & + & $1,2,5,6,34-36,41$ \\
\hline & & CTT & - & - & - & - & - & 41 \\
\hline
\end{tabular}


Table V. Polymorphisms of 5'-Flanking DNA, Intervening Sequences, and 3'-Untranslated DNA of the Insulin Receptor Gene

\begin{tabular}{|c|c|c|c|c|c|c|c|c|}
\hline Intron & Location & Nucleotide & A-1 & RM-1 & Lep/Winnipeg & Lep/Minn-1 & $\begin{array}{l}\text { Father of } \\
\text { Lep/Ark-1 }\end{array}$ & References \\
\hline \multirow[t]{2}{*}{ 5'-flanking } & -603 & A & - & & & + & & $34,39,40$ \\
\hline & & G & + & & & - & & 37 \\
\hline \multirow[t]{2}{*}{ 5'-flanking } & -500 & A & + & & & - & & 37 \\
\hline & & $\mathrm{G}$ & - & & & + & & $6,34,38,39,40$ \\
\hline \multirow[t]{2}{*}{2} & -4 & $(\mathrm{TC})_{10}$ & + & + & + & + & + & 33 \\
\hline & & $(\mathrm{TC})_{11}$ & + & - & - & + & - & \\
\hline \multirow[t]{2}{*}{6} & +31 & C & + & - & + & + & + & 33 \\
\hline & & $\mathrm{T}$ & + & + & - & + & + & \\
\hline \multirow[t]{2}{*}{6} & +43 & G & + & + & - & + & + & \\
\hline & & $\mathrm{T}$ & + & - & + & - & + & 33 \\
\hline \multirow[t]{2}{*}{8} & +27 & $\mathrm{C}$ & + & + & + & + & + & 33 \\
\hline & & $\mathrm{T}$ & - & - & - & + & - & \\
\hline \multirow[t]{2}{*}{8} & -4 & A & + & + & + & + & + & \\
\hline & & G & - & - & - & + & - & 33,34 \\
\hline \multirow[t]{2}{*}{8} & -20 & A & + & + & + & + & + & \\
\hline & & G & - & - & - & + & - & 33 \\
\hline \multirow[t]{2}{*}{ 3'-flanking } & 4,265 & A & - & - & - & + & - & 35 \\
\hline & & G & + & + & + & + & + & 34,36 \\
\hline
\end{tabular}

patients with leprechaunism had one allele with a nonsense mutation and a second allele with a different type of mutation: a missense mutation in leprechaun/Ark-1 (1) and a cis-acting mutation decreasing the level of mRNA in leprechaun/Minn1 (3).

Leprechaun/Winnipeg was a member of a consanguineous pedigree and was homozygous for a missense mutation in the insulin receptor gene (Table III). Previously, three other consanguineous pedigrees have been described in which the affected individuals were homozygous for a mutation in the insulin receptor gene: one kindred with leprechaunism (2) and two kindreds with type A extreme insulin resistance $(4,6)$.

\section{Nonsense mutations decrease levels of insulin receptor $m R N A$}

Two of the patients (A-1 and RM-1) in the present study were heterozygous for nonsense mutations in the insulin receptor gene. Previously, we have identified two nonsense mutations in the insulin receptor genes of two patients with leprechaunism $(1,3)$. In leprechaun/Minn-1, as with patients A-1 and $\mathrm{RM}-1$, the nonsense mutation is associated with a marked decrease in the level of mRNA transcribed from that allele (3). The present studies demonstrate the advantage of using genomic DNA rather than mRNA as template. In patients A- 1 and RM-1, mRNA transcribed from the alleles with the nonsense mutations is present in very low level relative to mRNA transcribed from the alleles with the missense mutation. Thus, it is unlikely that we would have detected the nonsense mutations if we had used a combination of reverse transcriptase and PCR to amplify mRNA.

In patient $\mathrm{A}-1$, a nonsense mutation was identified at codon 133 of exon 2 in one allele of the insulin receptor gene: a tryptophan codon $(T G G)$ was replaced by an amber stop codon $(T A G)$. Thus, the truncated receptor is a short fragment that would not be expected to be functional. In patient RM-1, a nonsense mutation was identified at codon 1,000 in exon 17 in one allele of the insulin receptor gene: an arginine codon
$(C G A)$ was replaced by an opal stop codon $(T G A)$. This nonsense mutation truncates the protein just before the ATP binding site of the tyrosine kinase domain. This truncated protein retains the extracellular domain as well as the transmembrane anchor. Thus, one might predict that the truncated receptor would retain the ability to bind insulin and would be expressed at the cell surface $(44,45)$. However, we obtained data that this nonsense mutation decreases the level of mRNA by $\sim 90 \%$ so that little of the truncated receptor is synthesized. These conclusions are consistent with our previous investigations of receptor biosynthesis in both patients' EBV-transformed lymphocytes. In those studies, we did not detect a truncated receptor molecule $(11,13)$.

Taira et al. (7) have described two patients (a mother and daughter) who are heterozygous for a deletion in the insulin receptor gene. Based on the nucleotide sequence of genomic DNA, they predict that the mRNA would encode a fusion protein that has an open reading frame for an additional 65 amino acids after the deletion break point at codon 1012. Data were not presented to indicate whether it is possible to detect mRNA transcribed from this mutant allele or the fusion protein it would encode. Nevertheless, it is possible that the abnormal stop codon introduced by the deletion would result in a low level of mRNA in much the same way we have observed with nonsense mutations.

\section{Missense mutations in the insulin receptor gene}

Lys $^{15}$ and $\mathrm{Arg}^{209}$ mutations. When the Lys ${ }^{15}$ and $\mathrm{Arg}^{209} \mathrm{mu}-$ tant receptors were expressed by transfection in NIH-3T3 cells (T. Kadowaki, H. Kadowaki, and S. I. Taylor, unpublished observations), both produced phenotypes very similar to that caused by the $\mathrm{Val}^{382}$ mutation described by Accili et al. (6). All three mutations impair posttranslational processing of the high mannose form of $\mathrm{N}$-linked carbohydrate to complex carbohydrate. Furthermore, all three mutations impair the transport of the receptor to the cell surface. It seems likely that these observations can be explained if the mutant receptors are im- 
paired in their ability to be transported through the endoplasmic reticulum and Golgi. Presumably, most of the patients' receptors fail to be transported to the compartment of the Golgi where the enzymes exist for processing of the N-linked carbohydrate. It is only a minority of the mutant receptors that undergo normal maturation of the $\mathrm{N}$-linked oligosaccharide, and it is only this minority of receptor molecules that are transported to the cell surface for insertion in the plasma membrane.

For normal intracellular transport of membrane proteins such as the insulin receptor to occur, it is necessary that the protein fold correctly within the rough endoplasmic reticulum and/or Golgi to form the normal three-dimensional structure. Mutations that disrupt the normal folding of the receptor can cause the phenotype of defective posttranslational processing and impaired intracellular transport, thereby reducing the number of insulin receptors on the cell surface. In this regard, it is relevant that $\mathrm{Asn}^{15}$ has been proposed to be the initial amino acid at the $\mathrm{NH}_{2}$ terminus of a predicted $\alpha$-helical domain of the insulin receptor (46). Furthermore, asparagine is conserved in this position in the IGF- 1 receptor $(47,48)$ and replaced by serine in the homologous position of the insulin receptor-related protein (49). As emphasized by Richardson and Richardson (50), asparagine and serine are the amino acids that are preferentially selected to be located at the "Ncap" position; i.e., at the $\mathrm{NH}_{2}$-terminal initiation of an $\alpha$-helical domain. In contrast, in as much as lysine is seldom present at the $\mathrm{N}$-cap of an $\alpha$-helical domain (50), the Lys ${ }^{15}$ mutation might be predicted to disrupt the $\alpha$-helix.

$\mathrm{His}^{209}$ is located in the cysteine-rich domain (amino acids 155-312) of the insulin receptor $\alpha$-subunit. Comparison of the amino acid sequences of the cysteine-rich domains of several receptors demonstrates that the amino acid residue $\mathrm{His}^{209}$ is highly conserved. There are seventeen cysteine residues that are conserved in the cysteine-rich domain of the human insulin receptor as well as the homologous domains of ten other receptors including the human and rat insulin-like growth factor-1 receptors $(47,48)$, the human and guinea pig insulin receptor-related proteins (49), the human, chicken, and drosophila epidermal growth factor receptors (52-54), the human and rat c-erb B-2 proteins $(55,56)$, and the human c-erb B-3 protein (57). Of the remaining 141 amino acids in the cysteine-rich domain, there are only two other amino acids that are identically conserved in all eleven receptors: $\mathrm{His}^{209}$ and Pro $^{219}$ :

$\begin{array}{lllllll}\text { Cys- } & \cdots & \text { - } & \text { Cys-Cys-His-X-X-Cys-X-X-X-Cys-X-X-Pro- } \cdots & & \text { - Cys. } \\ 155 & 207 & 209 & 212 & 216 & 219 & 312\end{array}$

The perfect conservation of $\mathrm{His}^{209}$ strongly suggests that it plays an important role in maintaining normal receptor structure.

$\mathrm{Ser}^{462}$-mutation. The amino acid $\mathrm{Asn}^{462}$ is conserved in all of the known sequences of the insulin receptor $(1-3,6,16,19$, $33-36,41,51)$ and also in two homologous proteins, the IGF-1 receptor (48) and the insulin-receptor related protein $(50)$. Moreover, Asn ${ }^{462}$ is nearby $\mathrm{Lys}^{460}$, the residue that was the locus of the missense mutation we have detected previously in the maternal allele of the insulin receptor gene of leprechaun/ Ark-1 (1). When the $\operatorname{Ser}^{462}$ mutant receptor was expressed by transfection in NIH-3T3 cells (T. Kadowaki, H. Kadowaki, and S. I. Taylor, unpublished observations), it produced a phe- notype very similar to that caused by the $\mathrm{Glu}^{460}$ mutation described previously (1). Both mutations $\left(\mathrm{Glu}^{460}\right.$ and $\mathrm{Ser}^{462}$ ) decrease the sensitivity of the receptor to changes in $\mathrm{pH}$. Thus, it seems likely that both mutations cause insulin resistance by similar mechanisms.

\section{Polymorphisms of the insulin receptor gene}

The amino acid sequence of the insulin receptor is conserved to a remarkable degree. Indeed, there are no confirmed examples of amino acid sequence polymorphisms in normal insulin receptors although several variant amino acids have been reported in individual cDNA clones $(35,36)$. It is possible that all of the reported amino acid polymorphisms result from cloning artifacts $(19,33,34)$. Nevertheless, a number of silent polymorphisms have been identified in the protein coding sequence as a result of alternate codon use (Table IV) and also in the sequences of several of the introns (Table V). These polymorphisms can be useful as markers to distinguish between the two alleles in an individual patient, and also as polymorphic markers for use in genetic linkage studies. In fact, it has been possible to identify multiple polymorphic markers to differentiate the two alleles of the insulin receptor gene in every patient we have studied except for those patients from consanguineous kindreds who are homozygous by descent $(1,3,6,8,41$; also, this report). Furthermore, application of PCR and allele-specific oligonucleotide hybridization may be a simpler way to screen large numbers of DNA samples than the conventional approach of screening for RFLPs by Southern blotting.

One of the polymorphisms that we have identified in the 5 -flanking DNA has the potential to be functionally important. That is the A vs. G polymorphism at nucleotide -603 in the binding site for $\mathrm{Spl}$ transcription factor (Table V). It has been suggested that this $\mathrm{Sp} 1$ binding site may be important in upregulating the expression of the insulin receptor gene (34, 37,39 ). Furthermore, Kadonaga et al. (43) have reviewed the effect of variations in the nucleotide sequence of the cis-acting element upon the binding affinity of the trans-acting factor $\mathrm{Sp} 1$. They concluded that $G G G G C G G G \underline{G C}$ is a stronger $\mathrm{Sp} 1$ binding site than the sequence $G G G G C G G G \underline{A}$. If these studies can be extrapolated to the situation in vivo with the 5'flanking DNA of the insulin receptor gene, then it is possible that the presence of $A$ at nucleotide -603 might be a risk factor predisposing to the development of insulin resistance. It would be difficult to investigate this hypothesis directly. Nevertheless, it might be possible to carry out epidemiologic studies to determine whether the presence of $A$ at nucleotide -603 is associated with noninsulin-dependent diabetes mellitus.

\section{Correlation of clinical syndromes with molecular defects}

Our observations support the previously published evidence $(1-8,19-21)$ that the syndromes of leprechaunism and type A insulin resistance are caused by mutations in the insulin receptor gene. In addition, another syndrome associated with extreme insulin resistance, the Rabson-Mendenhall syndrome, appears to be caused by a mutation in the insulin receptor gene. Defects in the function of IGF-1 receptors $(60,61)$ and EGF receptors (62) have also been described in fibroblasts from some patients with leprechaunism and other genetic forms of insulin resistance. However, the findings have not been observed in all patients $(60,62,63)$. Furthermore, unlike the situation with the insulin receptor gene, there is no evidence to document mutations in the genes encoding the re- 
ceptors for these other growth factors. It is possible that the insulin receptor may regulate the function of the receptors for IGF-1 or EGF. Mutations in the insulin receptor gene might indirectly impair the function of receptors for other growth factors. Thus, there is no need to postulate the existence of mutations in other genes to explain the pathogenesis of the syndromes of extreme insulin resistance. Rather, it seems likely that the mutations in the insulin receptor gene are sufficient to cause these syndromes.

What determines which syndrome a patient will develop? Because the clinical syndromes do not correlate with the type of mutation, it seems most likely that it is the severity of insulin resistance that determines the clinical manifestations. For example, patients with leprechaunism appear to have the most extreme degree of insulin resistance. All of the patients with leprechaunism have had two mutant alleles of the insulin receptor gene; two were compound heterozygotes $(1,3)$ and two were homozygotes (2; this report). Some patients with type A extreme insulin resistance have also been reported to have two mutant alleles: patient A-1 who is a compound heterozygote as well as two sisters in each of two consanguineous pedigrees, all of whom were homozygous for mutations in the insulin receptor gene $(4,6)$. However, some patients with type A extreme insulin resistance have appeared to be heterozygous for a single mutant allele of the insulin receptor gene $(5,7,8)$. As exemplified by the comparison between leprechaun/Ark-1 and her father (1), the degree of insulin resistance observed in heterozygotes is less severe than the insulin resistance in homozygotes and compound heterozygotes. As we have shown in the present work, the father of leprechaun/Ark-1 is heterozygous for a nonsense mutation in the insulin receptor gene while his other allele encodes a normal receptor. The presence of a second mutant allele in the daughter is the cause of her more severe degree of insulin resistance in addition to the multiple phenotypic abnormalities associated with the syndrome of leprechaunism $(1,30,32)$. Similarly, the mother of leprechaun/Winnipeg, an obligate heterozygote for the $\mathrm{Arg}^{209} \mathrm{mu}-$ tation, is insulin resistant and hyperinsulinemic (29). Thus, although the phenotype of leprechaunism is recessive, the phenotype of insulin resistance caused by the $\mathrm{Arg}^{209}$ mutation is inherited in a codominant fashion.

In conclusion, at least 13 point mutations have been identified in the insulin receptor gene (Fig. 2) (1-8, 19-21). These mutations provide insights into structure-function relationships of the insulin receptor and the molecular pathogenesis of genetic syndromes associated with extreme insulin resistance. The application of the polymerase chain reaction combined with direct sequencing of amplified DNA greatly facilitates identification of mutations. Thus, it will be possible to investigate a sufficiently large number of patients to estimate the frequency of mutations in the insulin receptor gene, and to determine whether mutations in this gene contribute to the pathogenesis of common diseases such as noninsulin-dependent diabetes mellitus.

\section{Acknowledgments}

We are grateful to Drs. S. Seino and G. I. Bell (Howard Hughes Medical Institute, University of Chicago) for generously providing us with partial nucleotide sequences for the introns of the insulin receptor gene, and guidance in designing primers for amplification of the DNA. We gratefully acknowledge many colleagues at National Institutes of
Health for helpful discussions and assistance in carrying out this work: Domenico Accili, Alessandro Cama, Eiichi Imano, Maxine Lesniak, Bernice Marcus-Samuels, Catherine McKeon, Victoria Moncada, Maria Rojeski, and Alan Shuldiner.

Dr. Hiroko Kadowaki was supported by a Mentor-Based Fellowship provided by the American Diabetes Association.

\section{References}

1. Kadowaki, T., C. L. Bevins, A. Cama, K. Ojamaa, B. MarcusSamuels, H. Kadowaki, L. Beitz, C. McKeon, and S. I. Taylor. 1988. Two mutant alleles of the insulin receptor gene in a patient with extreme insulin resistance. Science (Wash. DC). 240:787-790.

2. Klinkhamer, M., N. A. Groen, G. C. M. van der Zon, D. Lindhout, L. A. Sandkuyl, H. M. Krans, W. Möller, and J. A. Maassen. 1989. A leucine-to-proline mutation in the insulin receptor in a family with insulin resistance. EMBO (Eur. Mol. Biol. Organ.) J. 8:25032507.

3. Kadowaki, T., H. Kadowaki, and S. I. Taylor. 1990. A nonsense mutation causing decreased levels of insulin receptor mRNA: detection by a simplified technique for direct sequencing of genomic DNA amplified by polymerase chain reaction. Proc. Natl. Acad. Sci. USA. 87:658-662.

4. Yoshimasa, Y., S. Seino, J. Whittaker, T. Kakehi, A. Kosaki, H. Kuzuya, I. Imura, G. I. Bell, and D. F. Steiner. 1988. Insulin-resistant diabetes due to a point mutation that prevents insulin proreceptor processing. Science (Wash. DC). 240:784-787.

5. Moller, D. E., and J. S. Flier. 1988. Detection of an alteration in the insulin-receptor gene in a patient with insulin resistance, acanthosis nigricans, and the polycystic ovary syndrome (type $\mathrm{A}$ insulin resistance). N. Engl. J. Med. 319:1526-1529.

6. Accili, D., C. Frapier, L. Mosthaf, C. McKeon, S. C. Elbein, M. A. Permutt, E. Ramos, E. Lander, A. Ullrich, and S. I. Taylor. 1989. A mutation in the insulin receptor gene that impairs transport of the receptor to the plasma membrane and causes insulin resistant diabetes. EMBO (Eur. Mol. Biol. Organ.) J. 8:2509-2517.

7. Taira, M., M. Taira, N. Hashimoto, F. Shimada, Y. Suzuki, A. Kanatsuka, F. Nakamura, Y. Ebina, M. Tatibana, H. Makino, and S. Yoshida. 1989. Human diabetes associated with a deletion of the tyrosine kinase domain of the insulin receptor. Science (Wash. DC). 245:63-66.

8. Odawara, M., T. Kadowaki, R. Yamamoto, Y. Shibasaki, K. Tobe, D. Accili, C. Bevins, Y. Mikami, N. Matsuura, Y. Akanuma, F. Takaku, S. I. Taylor, and M. Kasuga. 1989. Human diabetes associated with a mutation in the tyrosine kinase domain of the insulin receptor. Science (Wash. DC). 245:66-68.

9. Taylor, S. I., B. Samuels, J. Roth, M. Kasuga, J. A. Hedo, P. Gorden, D. E. Brasel, T. Pokora, and R. R. Engel. 1982. Decreased insulin binding in cultured lymphocytes from two patients with extreme insulin resistance. J. Clin. Endocrinol. Metab. 54:919-930.

10. Kahn, C. R., and J. M. Podskalny. 1980. Demonstration of a primary (? genetic) defect in insulin receptors in fibroblasts from a patient with the syndrome of insulin resistance and acanthosis nigricans type A. J. Clin. Endocrinol. Metab. 50:1139-1141.

11. Hedo, J. A., V. Y. Moncada, and S. I. Taylor. 1985. Insulin receptor biosynthesis in cultured lymphocytes from insulin-resistant patients. J. Clin. Invest. 76:2355-2361.

12. Taylor, S. I., L. J. Underhill, J. A. Hedo, J. Roth, M. SerranoRios, and R. M. Blizzard. 1983. Decreased insulin binding to cultured cells from a patient with the Rabson-Mendenhall syndrome: dichotomy between studies with cultured lymphocytes and cultured fibroblasts. J. Clin. Endocrinol. Metab. 56:856-861.

13. Moncada, V. Y., J. A. Hedo, M. Serrano-Rios, and S. I. Taylor. 1986. Insulin-receptor biosynthesis in cultured lymphocytes from an insulin-resistant patient (Rabson-Mendenhall syndrome). Evidence for defect before insertion of receptor into plasma membrane. Diabetes. 35:802-807. 
14. Schilling, E. E., M. M. Rechler, C. Grunfeld, and A. M. Rosenberg. 1979. Primary defect of insulin receptors in skin fibroblasts cultured from an infant with leprechaunism and insulin resistance. Proc. Natl. Acad. Sci. USA. 76:5877-5881.

15. Atweh, G. F., H. E. Brickner, X.-X. Zhu, H. H. Kazazian, Jr., and B. G. Forget. 1988. New amber mutation in a $\beta$-thalassemic gene with nonmeasurable levels of mutant messenger RNA in vivo. J. Clin. Invest. 82:557-561.

16. Myerowitz, R., and F. C. Costigan. 1988. The major defect in Ashkenazi Jews with Tay-Sachs disease is an insertion in the gene for the $\alpha$-chain of $\beta$-hexosaminidase. J. Biol. Chem. 263:18587-18589.

17. Fojo, S. S., A. F. H. Stalenhoef, K. Marr, R. E. Gregg, R. S. Ross, and H. B. Brewer, Jr. 1988. A deletion mutation in the ApoC-II gene of a patient with a deficiency of apolipoprotein C-II. J. Biol. Chem. 263:17913-17916.

18. Urlaub, G., P. J. Mitchell, C. J. Ciudad, and L. A. Chasin. 1989. Nonsense mutations in the dihydrofolate reductase gene affect RNA processing. Mol. Cell. Biol. 9:2868-2880.

19. Taylor, S. I., T. Kadowaki, H. Kadowaki, D. Accili, A. Cama, and C. McKeon. 1990. Mutations in the insulin receptor gene in insulin resistant patients. Diabetes Care. 13:257-279.

20. Taylor, S. I., T. Kadowaki, D. Accili, A. Cama, H. Kadowaki, C. McKeon, V. Moncada, B. Marcus-Samuels, C. Bevins, K. Ojamaa, C. Frapier, L. Beitz, N. Perrotti, R. Rees-Jones, R. Margolis, E. Imano, S. Najjar, F. Courtney, R. Arakaki, P. Gorden, and J. Roth. 1990. Mutations in the insulin receptor gene in genetic forms of insulin resistance. Recent Prog. Horm. Res. In press.

21. Taylor, S. I., A. Cama, H. Kadowaki, T. Kadowaki, and D. Accili. 1990. Mutations of the human insulin receptor gene. Trends Endocrinol. Metab. 1:134-138.

22. Gibbs, R. A., P. N. Nguyen, L. J. McBride, S. M. Koepf, and C. T. Caskey. 1989. Identification of mutations leading to the LeschNyhan syndrome by automated direct DNA sequencing of in vitro amplified cDNA. Proc. Natl. Acad. Sci. USA. 86:1919-1923.

23. Wong, C., C. E. Dowling, R. K. Saiki, R. G. Higuchi, H. A. Erlich, and H. H. Kazazian, Jr. 1987. Characterization of $\beta$-thalassemia mutations using direct genomic sequencing of amplified single copy DNA. Nature (Lond.). 330:384-386.

24. Perez-Corral, F., S. de la Vina, M. Carbo, R. Barrio, R. Yturriaga, B. Perez-Meceda, M. Alonso, and M. Serrano-Rios. 1980. Rabson-Mendenhall syndrome: model of insulin resistance due to decreased number and affinity of insulin receptors in erythrocytes. Diabetologia. 19:306a. (Abstr.)

25. Kahn, C. R., J. S. Flier, R. S. Bar, J. A. Archer, P. Gorden, M. M. Martin, and J. Roth. 1976. The syndromes of insulin resistance and acanthosis nigricans. Insulin-receptor disorders in man. $N$. Engl. J. Med. 294:739-745.

26. Rosenberg, A. M., J. C. Haworth, G. W. Degroot, C. L. Trevanen, and M. M. Rechler. 1980. A case of leprechaunism with severe hyperinsulinemia. Am. J. Dis. Child. 134:170-175.

27. Elders, M. J., H. K. Schedewie, J. Olefsky, B. Givens, F. Char, D. M. Bier, D. Baldwin, R. H. Fiser, S. Seyedabadi, and A. Rubenstein. 1982. Endocrine-metabolic relationships in patients with leprechaunism. J. Natl. Med. Assoc. 74:1195-1210.

28. Taylor, S. I., J. Roth, R. M. Blizzard, and M. J. Elders. 1981. Qualitative abnormalities in insulin binding in a patient with extreme insulin resistance: decreased sensitivity to alterations in temperature and pH. Proc. Natl. Acad. Sci. USA. 78:7157-7161.

29. Taylor, S. I., B. Marcus-Samuels, J. Ryan-Young, S. Leventhal, and M. J. Elders. 1986. Genetics of the insulin receptor defect in a patient with extreme insulin resistance. J. Clin. Endocrinol. Metab. 62:1130-1135.

30. Ojamaa, K., J. A. Hedo, C. T. Roberts, Jr., V. Y. Moncada, P. Gorden, A. Ullrich, and S. I. Taylor. 1988. Defects in human insulin receptor gene expression. Mol. Endocrinol. 2:242-247.

31. Sambrook, J., E. F. Fritsch, and T. Maniatis. 1989. Molecular Cloning. A Laboratory Manual. 2nd Ed. Vol. 2. Cold Spring Harbor Laboratory, Cold Spring Harbor, NY. 1,546 pp.
32. Saiki, R. K., D. H. Gelfand, S. Stoffel, S. J. Sharf, R. Higuchi, G. T. Horn, K. B. Mullis, and H. A. Erlich. 1988. Primer-directed enzymatic amplification of DNA with a thermostable DNA polymerase. Science (Wash. DC). 239:487-491.

33. Seino, S., M. Seino, and G. I. Bell. 1990. Human insulin receptor gene: partial sequence and amplification of exons using the polymerase chain reaction. Diabetes. 39:123-128.

34. Seino, S., M. Seino, S. Nishi, and G. I. Bell. 1989. Structure of the human insulin receptor gene and characterization of its promoter. Proc. Natl. Acad. Sci. USA. 86:114-118.

35. Ullrich, A., J. R. Bell, E. Y. Chen, R. Herrera, L. M. Petruzzelli, T. J. Dull, A. Gray, L. Coussens, Y. C. Liao, M. Tsubokawa, A Mason, P. H. Seeburg, C. Grunfeld, O. M. Rosen, and J. Ramachandran. 1985. Human insulin receptor and its relationship to the tyrosine kinase family of oncogenes. Nature (Lond.). 313:756-761.

36. Ebina, Y., L. Ellis, K. Jarnagin, M. Edery, L. Graf, E. Clauser, J. H. Ou, F. Masiarz, Y. W. Kan, I. D. Goldfine, R. A. Roth, and W. J. Rutter. 1985. The human insulin receptor cDNA: the structural basis for hormone-activated transmembrane signalling. Cell. 40:747-758.

37. Araki, E., F. Shimada, H. Uzawa, M. Mori, and Y. Ebina. 1987. Characterization of the promoter region of the human insulin receptor gene. J. Biol. Chem. 262:16186-16191.

38. Mamula, P. W., K. Y. Wong, B. A. Maddux, A. R. McDonald, and I. D. Goldfine. 1988. Sequence and analysis of promoter region of human insulin-receptor gene. Diabetes. 37:1241-1246.

39. Tewari, D. S., D. M. Cook, and R. Taub. 1989. Characterization of the promoter region and 3'-end of the human insulin receptor gene. J. Biol. Chem. 264:16238-16245.

40. McKeon, C., V. Moncada, T. Pham, P. Salvatore, T. Kadowaki, D. Accili, and S. I. Taylor. 1990. Structural and functional analysis of the insulin receptor promoter. Mol. Endocrinol. 4:647-656.

41. Cama, A., A. P. Patterson, T. Kadowaki, H. Kadowaki, G. Siegel, D. D'Ambrosio, S. Lillioja, J. Roth, and S. I. Taylor. 1990. The amino acid sequence of the insulin receptor is normal in an insulin resistant Pima Indian. J. Clin. Endocrinol. Metab. 70:1155-1161.

42. Frohman, M. A., M. K. Dush, and G. R. Martin. 1988. Rapid production of full-length cDNAs from rare transcripts: amplification using a single gene-specific oligonucleotide primer. Proc. Natl. Acad. Sci. USA. 85:8998-9002.

43. Kadonaga, J. T., K. A. Jones, and R. Tjian. 1986. Promoterspecific activation of RNA polymerase II transcription by Sp1. Trends Biochem. Sci. 11:20-23.

44. Whittaker, J., and A. Okamoto. 1988. Secretion of soluble functional insulin receptors by transfected NIH3T3 cells. J. Biol. Chem. 263:3063-3066.

45. Johnson, J. D., M. L. Wong, and W. J. Rutter. 1988. Properties of the insulin receptor ectodomain. Proc. Natl. Acad. Sci. USA. 85:7516-7520.

46. Bajaj, M., M. D. Waterfield, J. Schlessinger, W. R. Taylor, and T. Blundell. 1987. On the tertiary structure of the extracellular domains of the epidermal growth factor and insulin receptors. Biochim. Biophys. Acta. 916:220-226.

47. Gray, A., A. W. Tam, T. Yang-Feng, M. Tsubokawa, C. Collins, W. Henzel, T. Le Bon, S. Kathuria, E. Chen, S. Jacobs, U. Francke, J. Ramachandran, and Y. Fujita-Yamaguchi. 1986. Insulinlike growth factor I receptor primary structure: comparison with insulin receptor suggests determinants that define functional specificity. EMBO (Eur. Mol. Biol. Organ.) J. 5:2503-2512.

48. Werner, H., M. Woloschak, M. Adamo, A. Shen-Orr, C. T. Roberts, Jr., and D. LeRoith. 1989. Developmental regulation of the rat insulin-like growth factor I receptor gene. Proc. Natl. Acad. Sci. USA. 86:7451-7455.

49. Shier, P., and V. M. Watt. 1989. Primary structure of a putative receptor for a ligand of the insulin family. J. Biol. Chem. 264:1460514608.

50. Richardson, J. S., and D. C. Richardson. 1988. Amino acid preferences for specific locations at the ends of $\alpha$-helices. Science (Wash. DC). 240:1648-1652. 
51. Moller, D. E., A. Yokota, and J. S. Flier. 1989. Normal insulin-receptor cDNA sequence in Pima Indians with NIDDM. Diabetes. 38:1496-1500.

52. Ullrich, A., L. Coussens, J. S. Hayflick, T. J. Dull, A. Gray, A. W. Tam, J. Lee, Y. Yarden, T. A. Libermann, J. Schlessinger, J. Downward, E. L. V. Mayes, N. Whittle, M. D. Waterfield, and P. H. Seeburg. 1984. Human epidermal growth factor receptor cDNA sequence and aberrant expression of the amplified gene in A431 epidermoid carcinoma cells. Nature (Lond.). 309:418-425.

53. Lax, I., A. Johnson, R. Howk, J. Sap, F. Bellot, M. Winkler, A. Ullrich, B. Vennstrom, J. Schlessinger, and D. Givol. 1988. Chicken epidermal growth factor (EGF) receptor: cDNA cloning, expression in mouse cells, and differential binding of EGF and transforming growth factor alpha. Mol. Cell. Biol. 8:1970-1978.

54. Livneh, E., L. Glazer, D. Segal, J. Schlessinger, and B. Z. Shilo. 1985. The Drosophila EGF receptor gene homolog: conservation of both hormone binding and kinase domains. Cell. 40:599-607.

55. Yamamoto, T., S. Ikawa, T. Akiyama, K. Semba, N. Nomura, N. Miyajima, T. Saito, and K. Toyoshima. 1986. Similarity of protein encoded by the human c-erb-B-2 gene to epidermal growth factor receptor. Nature (Lond.). 319:230-234.

56. Bargmann, C. I., M. C. Hung, and R. A. Weinberg. 1986. The neu oncogene encodes an epidermal growth factor receptor-related protein. Nature (Lond.). 319:226-230.

57. Kraus, M. H., W. Issing, T. Miki, N. C. Popescu, and S. A. Aaronson. Isolation and characterization of ERBB3, a third member of the ERBB/epidermal growth factor receptor family: evidence for overexpression in a subset of human mammary tumors. Proc. Natl. Acad. Sci. USA. 86:9193-9197.

58. Yip, C. C., H. Hsu, R. G. Patel, D. M. Hawley, B. A. Maddux, and I. D. Goldfine. 1988. Localization of the insulin-binding site to the cysteine-rich region of the insulin receptor $\alpha$-subunit. Biochem. Biophys. Res. Commun. 157:321-329.

59. Waugh, S. M., E. E. DiBella, and P. F. Pilch. 1989. Isolation of a proteolytically derived domain of the insulin receptor containing the major site of cross-linking/binding. Biochemistry. 28:3448-3455.
60. Van Obberghen-Schilling, E. E., M. M. Rechler, J. A. Romanus, A. B. Knight, S. P. Nissley, and R. E. Humbel. 1981. Receptors for insulinlike growth factor I are defective in fibroblasts cultured from a patient with leprechaunism. J. Clin. Invest. 68:1356-1365.

61. Massague, J., G. F. Freidenberg, J. M. Olefsky, and M. P. Czech. 1983. Parallel decreases in the expression of receptors for insulin and insulin-like growth factor I in a mutant human fibroblast line. Diabetes. 32:541-544.

62. Reddy, S. S. K., and C. R. Kahn. 1989. Epidermal growth factor receptor defects in leprechaunism. A multiple growth factor-resistant syndrome. J. Clin. Invest. 82:1359-1365.

63. Podskalny, J. M., and C. R. Kahn. 1982. Cell culture studies on patients with extreme insulin resistance. I. Receptor defects on cultured fibroblasts. J. Clin. Endocrinol. Metab. 54:261-268.

64. DeMeyts, P., J.-L. Gu, R. M. Shymko, B. E. Kaplan, G. I. Bell, and $J$. Whittaker. 1990. Identification of a ligand binding region of the human insulin receptor encoded by second exon of the gene. $\mathrm{Mol}$. Endocrinol. 4:409-416.

65. Frias, I., and S. M. Waugh. 1989. Probing the $\alpha-\alpha$ subunit interface region in the insulin receptor, location of interhalf disulfide(s). Diabetes. 38(Suppl. 2):60A (Abstr.)

66. Seino, S., and G. I. Bell. 1989. Alternative splicing of human insulin receptor messenger RNA. Biochem. Biophys. Res. Commun. 159:312-316.

67. Moller, D. E., A. Yokota, J. F. Caro, and J. S. Flier. 1989. Tissue-specific expression of two alternatively spliced insulin receptor mRNAs in man. Mol. Endocrinol. 3:1263-1269.

68. White, M. F., S. E. Shoelson, H. Keutmann, and C. R. Kahn. 1988. A cascade of tyrosine autophosphorylation in the beta-subunit activates the phosphotransferase of the insulin receptor. J. Biol. Chem. 263:2969-2980.

69. Tornqvist, H. E., J. R. Gunsalus, R. A. Nemenoff, H. R. Frackelton, M. W. Pierce, and J. Avruch. 1988. Identification of the insulin receptor tyrosine residues undergoing insulin-stimulated phosphorylation in intact rat hepatoma cells. J. Biol. Chem. 263:350-359. 